\title{
ELECTRONIC EVIDENCE IN THE ADMINISTRATIVE PROCEDURE IN UKRAINE IN THE LIGHT OF THE INFORMATIONAL APPROACH
}

The purpose of the scientific paper is to develop solutions for the improvement of the electronic
evidence sub-institute in the administrative procedure in Ukraine based on the informational
approach. The methodological framework for the research is represented by theoretical
advances in the field ofprocedural law, with an emphasis on the theory of evidence and proof, as
well as computer forensics, information law and technical literature. Comparative and formal
legal methods, structural-functional analysis, inductive and deductive reasoning have been
used to conduct the research. As a result of the research the analysis of the current theoretical
developments in the study of the interdisciplinary sub-institute of the electronic evidence has
been conducted; scientific comparison between the "objective" (traditional to the domestic
theory of proof) and "informational" approaches to the definition of electronic evidence
has been carried out; main theoretical and practical issues, arising from the application
of different approaches to the perception of electronic evidence have been discovered
and propositions for legislative amendments were made. Key findings of the study are briefly
summarized below. In determination of the concept and the essence of electronic evidence
an optimal combination of both objective and informational approaches to the perception
of the electronic evidence should be applied. Differentiation between the original and the copy
of electronic evidence should not be abandoned, and it should be allowed for the court to
substantiate its findings with the copies of the electronic evidence in specific cases. Particular
amendments to the Code of Administrative Procedure of Ukraine should be made with
respect to: the definition of the original and the copy of electronic evidence; legal regulation
of particular issues concerned with the use of originals and copies of the electronic evidence
when proving the factual circumstances of the case (as well as when rendering the final
and interim decisions by the court and when using the special knowledge) - primarily, in
compliance with technical standards, that have recently been approved in Ukraine, regulating
certain issues on the processing of electronic digital evidence.
Key words: ectronic (digita)

Key words: electronic (digital) data, judicial procedure, Code of Administrative Procedure of Ukraine, original of electronic evidence, copy of electronic evidence. 


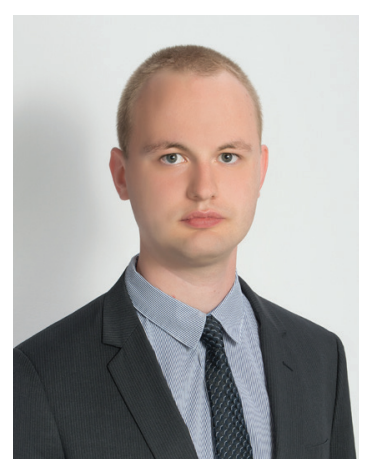

Vitalii Budkevych, Postgraduate Student at the Department of Public Administration and Governance National Academy of Internal Affairs https://orcid.org/0000-00034692-4818

v.budkevych.legal.science.ua@ gmail.com

\section{Introduction}

The separation in 2017 of the interdisciplinary sub-institute of electronic digital evidence in judicial procedure created more favorable conditions for the use of electronic digital data in justice. That was particularly important in the view of the absence of a uniform approach to the categorization of electronic digital data in terms of certain means of proof: in the Code of Administrative procedure of Ukraine (hereinafter referred to as "CAP of Ukraine") electronic documents had been long considered as written evidence, while audio and video recordings - as real evidence, until respective provisions of the Code were amended in 2017.

However, yet even the renewed legislation (amended by the Law No. 2147-VIII) has not solved all of the problematic issues. In legal science today still remains perhaps as the most conceptual issue the choice of an approach to understanding electronic evidence: either "objective" or "informational" (both of which regard the criterion of the degree of connectedness of electronic data to its primary medium). In practice, there still remain not entirely clear criterions for distinguishing the original and copies of electronic data, the way of certification of the paper and electronic copies of electronic evidence, the procedure for collection (fixation) of certain types of electronic evidence.

At the same time it worth noting, that in Ukraine even before the legislative implementation of the sub-institute of electronic evidence (with regard to foreign experience and technological trends) there has been rising an increasing interest among legal scientists to the regulation of the use of electronic (digital) data in different types of judicial procedure. Among first Ukrainian scholars conducting researches in question were D.M. Tsekhan, Krytska O.I. (criminal procedure), A. Yu. Kalamaiko, Yu.S. Pavlova and others. In 2016 there was published a monograph entitled "Electronic means of proof in civil procedure", prepared by A. Yu. Kalamaiko. After the implementation of the sub-institute of electronic evidence into Ukrainian procedural codes scientific developments in the stated area moved on to more practical concerns. In 2019 there was published a dissertation entitled "Electronic document as a source of evidence in civil procedure", prepared by Yu. S. Pavlova. Also at the present stage following 
Ukrainian scholars are conducting researches related to electronic evidence: O.S. Chornyi, O.I. Antoniuk, O.Iu. Husiev, M. Hetmantsev, V.S. Petrenko, K.B. Drohoziuk, M.V. Pushkar, S.Ia. Fursa, O.M. Lazko, O.V. Sirenko, A.S. Shtefan, N.Y. Holubieva, Moskovchuk D.O. (civil procedure), K.O. Zerov (intellectual property law), H.O. Kurtakova, A.M. Naichenko, V.I. Drishliuk (commercial procedure), A.V. Stolitnii, I.H. Kalancha, O.P. Metelev, V.H. Khakhanovskyi, M.V. Hutsaliuk (criminal procedure), I.V. Kazachuk, S.S. Yesimov (proceedings for an administrative offence), V.V. Muradov (forensic aspect) and others. Within the framework of the administrative procedure following Ukrainian scholars devoted their studies to the examination of certain aspects of the use of electronic evidence in judicial proceedings: N. Blazhivska, O.V. Haran, Ya.S. Kalmykova, A.V. Zlenko, H.V. Muliar, O.S. Khovpun, D.I. Holopapa.

The purpose of the study is to define with the use of the informational approach possible theoretical and practical solutions to the problems related to functioning of the sub-institute of electronic evidence in administrative procedure. To achieve the goals of the study following tasks are to be carried out: 1) identification of the main controversies and problems, in particular, those arising in judicial practice of the administrative courts of Ukraine with regard to the application of legislative provisions, regulating the interdisciplinary sub-institute of electronic digital evidence; 2) assessment of the extent to which the problematic issues have been formerly examined; 3) formulating proposals for resolving of the current problems; 4) defining subsequent research directions.

\section{Defining the concepts "evidence" and "means of proof". Application of the "objective" approach}

Yu. S. Pavlova, with reference to I.V. Sukhanov, notes that the definition of the concept "evidence" has long been controversial, resulting in development of three main conceptions of what is meant by the term "judicial evidence": 1) evidence as merely factual data (in 2002 this definition was transformed into "information on facts"); 2) evidence as a combination of factual data (information on facts) and means of proof; 3 ) evidence as either factual data (information on facts) or means of proof, differently in every single case depending upon the context (the theory of dual understanding of judicial evidence) (Pavlova, 2019). According to A.Yu. Kalamaiko this list may be supplemented by two other conceptions, under which: 4) means of proof include evidence and means of its collection; 5) evidence and means of proof are treated as equal (Kalamaiko, 2016). Without resorting to deep analysis of each of outlined above conceptions of evidence, it should be mentioned that the conception defining evidence as a combination of factual data and means of proof seems to be the most exact and reasonable taking into account existing scientific researches and legislative provisions. The analysis of the stated position is given below.

A.Yu. Kalamaiko defines evidence as "a concept, that connects factual data and means of proof as the content and its procedural form" and emphasizes that 
"unlike the scientific and logical evidence, judicial ones have the prescribed by the law procedural forms, which are means of proof. It is important to distinguish the form of existence and the expression of the content of evidence, that is, on the one hand, what is characteristic of evidence as a phenomenon of the outside world, and on the other hand - the procedural form, prescribed by the law. The form of the information - signs, spoken word, real code - provide access of conscience to the content of the evidence. The content and the form of the evidence are indivisible and constitute a single concept "evidence" (Kalamaiko, 2016). In our view, that means that the concepts of the written and real evidence combine both the tangible medium with certain signs or specific properties (means of proof/procedural form of evidence) and the information encoded in the mentioned signs or properties (the content of the evidence). Consequently, when referring to written and real evidence the "objective" approach is to be applied, according to which the "encoded" information is integral to its medium (Luspenyk \& Mamchenko, 2018). Such an approach is currently implemented in Ukrainian procedural law.

\section{Electronic evidence: applying the "informational approach"}

Primarily, it should be noted that today the majority of legal scholars, based on the technical researches, international standards and recommendations, and legislative provisions, support the so-called "informational approach". Such an approach could be defined through the properties of electronic data, for example: intangible form of digital data, the absence of an integral link to its medium (the possibility of changing the medium without loss of data), need for application of tools for "reading" the electronic information as well as the "absence of the concept "original" of electronic means of proof due to the complete identity of the electronic copies" (Kalamaiko, 2016; Pavlova, 2019). In this regard D.D. Luspenyk notes that since according to respective provisions of procedural law "electronic evidence is defined as information ", then such a definition "... is an example of an informational approach"; whereas "written evidence are defined as documents" and "real evidence are defined as objects of the material world" and "obviously, the last two definitions refer to a particular material object, that is to say the legislator uses the "objective" approach" (Luspenyk \& Mamchenko, 2018).

It is also worth noting, that in the context of the procedural form of the electronic evidence it would be reasonable to refer to the term "data". M.V. Bryzhko points out that within the electronic environment "data may be regarded as formalized combinations comprised of signs and code, that provide information and are designed to its automatic processing". At the same time in respect of "information on facts" M.V. Bryzhko emphasizes that "only the human may possess the knowledge, and only for human the variety of graphical symbols may serve as "information on facts" (Bryzhko, 2011). Basically such a position complies with the respective provisions of the Law of Ukraine "On information", where in paragraph 1 of the Article 1, when giving the definition of "information", distinction is made between the concepts of "data" and "information on facts". In the Law 
of Ukraine "On Electronic documents and electronic workflows" data is specified as "information, presented in the form that is suitable for its processing by electronic tools". In the Requirements for the Data Formats in Electronic Workflows in State Authorities, approved by the Order No 60 of 07.09 .2016 of the State Agency on E-Governance of Ukraine electronic data is defined as "files, electronic signatures, electronic stamps which are used to certify certain data of respective files, folders and metadata that are contained in a container". A.Yu. Kalamaiko states that "the broadest concept in electronic sphere is the "file" as a unit of creation, preservation and transmission of the information in the electronic environment. A file may contain audio-and video information, graphic images, including electronic documents and messages, in other words, is an equivalent to the concept "real evidence" in electronic sphere" (Kalamaiko, 2016).

It seems appropriate that the shift from the objective to informational approach at the legislative level most broadly shows itself in the sphere of document management. While in part 1 of the Article 1 of the Law of Ukraine "On information" document is defined as "a tangible medium, containing information, the main functions of which are preserving and transmitting information over time and space", at the same time in paragraph 1 of the Article 5 of the Law of Ukraine "On Electronic documents and electronic workflows" document is articulated as a "document, the information in which is recorded in the form of electronic data, including obligatory requisites of the document". As noted by D.D. Luspenyk and O.Yu. Husiev the informational approach is in line with the international standards of the International Organization of Standardization in the area of document management (Luspenyk \& Mamchenko, 2018; Husiev, 2019). In fact, as of today the International Organization of Standardization issued more than a dozen of international standards, that directly or indirectly regulate various aspects of using electronic data in document management (creation, preservation, transmission and destruction), and are based on informational approach.

4. Distinguishing copies and originals of electronic evidence. Other related evidentiary issues

It is specified in paragraphs 2 and 3 of the Article 99 of the Code of Administrative Procedure of Ukraine (hereinafter referred to as CAP of Ukraine) that electronic evidence should be submitted in originals or in copies that are certified by an electronic digital signature, or in paper copies. According to paragraph 4 of the Article 99 of CAP of Ukraine case participant, who is submitting a copy of electronic evidence, has to provide information on possession of the original of the electronic evidence by himself or by other persons. In paragraph 5 of the Article 99 of CAP of Ukraine it is enshrined that should the copy (or paper copy) of the electronic evidence be submitted, the court may request from the respective person the original of the electronic evidence upon the motion of the party or on its own initiative. In case the original of the electronic evidence is not submitted and the case participant challenges the authenticity of the copy (paper copy) of the original, the court does not take account of that evidence. 
Notwithstanding the fact that the concepts of the "original" and the "copy" of electronic evidence are not directly defined in the procedural law, an expected and reasonable case law has been developed on the stated point: the authentic electronic data on the primary medium is generally treated as the original of the electronic evidence, while the copy is referred to as any reproduction of the authentic data on a different medium, than the primary (See, for example, the decisions of the Second Appellate Administrative Court Decision of February 2, 2020 in case No 584/1572/19; Khersonskyi Circuit Administrative Court Decision of December 06, 2018 in case No 2140/1315/18; Polonskyi disctrict court of the Khmelnytskyi region decision of April 19, 2018 in case No. 681/276/18).

As indicated above, somewhat more pronounced informational approach is being applied with respect to electronic documents (see, for example, the abovementioned Decision of December 06, 2018 in case No 2140/1315/18). Unlike the copy of the electronic document, certain exemplar of the electronic document is treated as an original not owing to the fact that electronic data has been initially created on certain primary medium, but due to the fact that this electronic data contains specific legally relevant requisites, and its authenticity and integrity is certified with the electronic digital signature of the author of the document (Pavlova, 2019). Precisely enough such an approach has been set out in the draft of The Regulations on the Unified court informational telecommunication system (an informal text), wherein the electronic copy of the electronic document is defined as "a document in electronic form, containing the visual image of the other electronic document without the qualified electronic digital signature of its author (authors). The authenticity and the legal status of the electronic copy of the electronic document is certified with the electronic signature of the person, who is not the author of that document". The definition for the original of the electronic document in the stated Regulation was used the same as that established in the Law of Ukraine "On electronic documents and electronic workflows" as follows: "the document, information in which is recorded in electronic data, including the compulsory requisites of the document, the legal status of which is certified with the qualified electronic signature of the author" (The Regulations on the Unified court informational telecommunication system (informally published text, 2019).

It also should be noted that controversial enough is the judicial practice on using of paper copies of electronic evidence. Primarily, that regards printouts and screenshots.

For instance, in its decision of June 12, 2019 in case No 520/9482/18 the Second Appellate Administrative Court accepted as evidence a screenshot without taking additional measures to verify such a paper copy of electronic evidence.

In other cases, there are frequently found court's refusals to accept the paper copy of the electronic evidence in the absence of its original (see, for example, the Kyiv Circuit Administrative Court in its decision of March 13, 2020 in case No 640/13066/19). 
At once we shall notice, that in this regard a well-grounded seems to be the position set out in the explanation note to the Guidelines of the Committee of Ministers of the Council of Europe on electronic evidence in civil and administrative proceedings, adopted by the Committee of Ministers on 30 January 2019, at the 1335th meeting of the Ministers' Deputies, where it was stated in paragraph 27 that "Printouts of electronic evidence can be easily manipulated as they exclude metadata or other hidden data. Consequently, a screen printout from a web browser is not reliable evidence as it is nothing but a copy of the screen dis-play. It can be modified in a very simple manner because no special software or hardware are required for this purpose" (Guidelines of the Committee of Ministers of the Council of Europe on electronic evidence in civil and administrative proceedings and the explanation note thereto, 2019).

In our view, paper copies of electronic evidence might be used at the time of submission of the statement of claim (for convenience), or in particular cases at later stages of the proceeding, provided that certain fact or circumstance is undoubtedly proved with the body of evidence in the case.

But as a common rule rather the submission of the evidence in electronic form is recommended.

In general, as of today there are in the Ukrainian legal science three main positions with regard to the necessity and the way of distinguishing of the originals and the copies of the electronic evidence:

1). Objection of the necessity of distinguishing the concepts "original" and "copy" of the electronic evidence. The outlined position in practical terms is based upon the rationale that the copy of electronic digital data is identical to its original, and in the theoretical context it relies on the informational approach to the definition of the "evidence" concept (Husiev, 2019).

2). Those who advocate the second of the positions call on to distinguish the concepts "original" and "copy" of electronic evidence merely with regard to particular types of electronic evidence ("the midpoint position") (Chornyi \& Antoniuk, 2018).

3). Those who uphold the need to distinguish between the concepts "original" and "copy" of electronic evidence (Shtefan A.S.).

This position (the third of the ones listed above) does not contradict the data contained in technical literature. For example, according to M.M. Fedotov to perform an expert examination in particular cases the original of the authentic electronic data on the primary medium is needed. In other cases, it is acceptable to use the copy of electronic data, copied by the expert from the primary medium (Fedotov, 2007). In this case E. Casey puts stress on the correctness of the data copying, in order to prevent errors in the data as well as its loss, corruption and misrepresentation (Casey, 2010).

In addition, for example, in paragraph 30 of the Guidelines of the Committee of Ministers of the Council of Europe on electronic evidence in civil and administrative 
proceedings is implied a situation when for proper examination of the electronic data it may be needed to get access to the cloud service provider's hardware (Guidelines of the Committee of Ministers of the Council of Europe on electronic evidence in civil and administrative proceedings and the explanation note thereto, 2019).

\section{Outlining propositions for legislative amendments}

In our view, each of the three above - mentioned positions is based on the same theoretical and practical developments in the field of technical sciences. Therefore, most of the controversies occur due to lack of coherence with regard to the legal framework of the use of electronic data in judicial proceedings and articulation of the respective legal rules in terms of juridical technique.

Below there are provided technically founded provisions that neither of the representatives of all of the three positions deny and which enable us to formulate the alternative version of the respective articles:

1. Electronic data that is primarily created and stored on certain medium may play a significant probative role specifically with respect to the connection that is has with the particular medium (as well as for the conduction of the expert examination of the respective electronic data). When copying or transmitting electronic data through communication channels, errors in data (including metadata) or its loss may occur, or data may be corrupted, destroyed fully or in part either intentionally or recklessly, what will make it impossible to fully establish the circumstances of the case.

2. Given that copying or transmitting of the electronic data is conducted in the proper way it may be transferred without the loss of its original content and specific features. That is why in particular cases insignificant distinctions between the original and the copy of the electronic data may be ignored without a threat to the establishment of the factual circumstances of the case due to the high degree of likeness of both data exemplars.

3. With regard to certain types of the electronic data, namely, electronic documents there are distinctions drawn by virtue of law between the originals and the copies thereof through establishment of respective requisites (primarily, the electronic digital signature), which are designed to certify the authenticity of the original and differentiate it from the copy.

4. Certification of the paper copies of the electronic evidence may be conducted in the manner, provided for written evidence (paper documents).

Having synthesized the aforementioned as well as particular legislative provisions and scientific and practical ideas one can come to conclusions, on the basis of which certain propositions on the amendment of the current legislative provisions can be made. The main ones are summarized below:

1. We consider inappropriate the abandonment of the concepts "the original of the electronic evidence" as authentic electronic data created and stored on its primary medium and "the copy of the electronic evidence" as electronic data, created through the reproduction of the authentic electronic data including the cases when it is stored on the "secondary" medium. 
With regard to electronic documents we propose to define the concepts of the original and the copy in the way provided for in the Law of Ukraine "On the electronic documents and electronic workflows".

The stated approach would not contradict the legal positions and recommendations of the international institutions. For it was indicated, for example, in paragraph 28 of the decision of the ECHR in case García Ruiz v. Spain, No 30544/96 that "While Article 6 of the Convention guarantees the right to a fair hearing, it does not lay down any rules on the admissibility of evidence or the way it should be assessed, which are therefore primarily matters for regulation by national law and the national courts..." (Guidelines of the Committee of Ministers of the Council of Europe on electronic evidence in civil and administrative proceedings and the explanation note thereto, 2019).

2. If the participant of the case possesses the original of the electronic evidence and its submission is not connected to or does not entail any difficulties or negative consequences, the participant is obliged to provide to the court such an original on its primary medium on the court's request.

3. At the same time the court should not request the original of the electronic evidence merely on formalistic grounds. In every case when such a decision is to be taken it should be motivated and grounded. Furthermore, there should be provided for in the legislation a benchmark when it is recommended or obligatory for the court to request the medium and when not. However, the stated provisions should not undermine the discretion of the court and the limits of its inner conviction.

In other words, the legal mechanism that is proposed herein could function as follows: the participant of the case shall submit the copy of the electronic evidence. The court shall be empowered to request its original, while the legislation shall contain a set of conditions (circumstances) under which the court shall establish the fact based on the copy of the electronic evidence.

4. We consider it also reasonable to adopt separate provisions on engagement of the specialist for preparation of the electronic evidence for its submission to the court and recording (protocolling) all of such preparative actions. Unlike the criminal proceeding, in administrative proceedings this issue is not comprehensively regulated (particularly in the light of the recent adoption of the State Standard of Ukraine ISO/IEC 27037:2017 "Information technology - Security techniques - Guidelines for identification, collection, acquisition and preservation of digital evidence").

Despite the different procedural forms (including the rules on evidence and proof), in our view, the use of special knowledge and thorough recording of the preparatory actions (processes) shall contribute to the efficient and objective examination of the submitted electronic evidence.

5. In our view, it would be appropriate to reduce the time for the consideration of the claim of securing electronic evidence given the fragility of the electronic data. The effectiveness of respective provisions in this particular case, not least, depends on timeliness of its application. 


\section{Conclusions}

In the theory of evidence and proof there are existing different approaches to the understanding of the concept of evidence. Most broadly supported is the definition, which combines information as the content of evidence and means of proof as its procedural form. With respect to real and written evidence the objective approach should be used, according to which the medium is an integral part of the evidence. Taking into account the essence of electronic evidence, the informational approach should be applied, under which a certain ordered set of electronic data is in itself an autonomous object of informational and evidentiary activities. The difference between the concepts "information" and "data" is pointed out, when the first is the content of a piece of electronic evidence, and the latter - its procedural form. "Data" is defined as combinations of signs and codes that are designed for their automatic processing. "Information on facts" is information in the form, available for human perception.

When distinguishing originals and copies of electronic evidence it is proposed to treat as the "originals" the authentic electronic data created and stored on the primary medium, and the "copies" thereof - as electronic data, created through the reproduction of the authentic electronic data, including its storing on the other medium than the primary.

Somewhat specific approach is applied to the distinction of the originals and the copies of electronic documents. By virtue of law the original is distinguishable from the copy primarily by the electronic digital signature of the author of such a document.

Given the high degree of similarity of the copies and the originals of electronic evidence it is proposed where there are respective grounds (for instance, in case of loss or destruction of the originals) to accept the electronic copies of the electronic evidence instead of the originals, provided there are not any doubts as to the relevance, admissibility and reliability of the evidence in question.

It is also recommended to apply special knowledge not only when examining electronic evidence, but also in the process of its preparation for the submission to the court.

Among other proposed legislative amendments is the reducing of the time frame for the consideration of applications for securing evidence in the view of the fragility of electronic data and, consequently, the existing necessity for taking timely and effective measures.

In the longer term it is considered appropriate to articulate the responsibility for committing unlawful acts with regard to electronic evidence (in particular, impeding submission to the court, corrupting, destructing), including acts qualified as criminal. Also the start of functioning of the Unified Court informational telecommunication system is essential. Except the separate regulation on the work of such a system, it is necessary that special regulations on processing and submitting of electronic evidence be adopted. 
Bibliography:

1. Casey E. Handbook of digital forensics and investigation. Burlington, USA, 2010. 567 p.

2. Guidelines of the Committee of Ministers of the Council of Europe on electronic evidence in civil and administrative proceedings, Adopted by the Committee of Ministers on 30 January 2019, at the 1335th meeting of theMinisters' Deputies and the Explanation note thereto. URL: https://rm.coe.int/guidelines-on-electronic-evidence-and-explanatory-memorandum/ 1680968ab5 (дата звернення: 29.04.2020)

3. International Organization for Standardization. Information technology - Security techniques - Guidelines for identification, collection, acquisition and preservation of digital evidence (ISO/IEC Standard No. 27037:2012). URL: https://www.iso.org/standard/44381.html (Дата звернення: 29.04.2020)

4. Mason S. \& Stanfield A. (n.d.). Authenticating electronic evidence. In S. Mason \& D. Seng (2017), (Eds.), Electronic Evidence: Fourth Edition (pp.193-260). http://dx.doi.org/10.14296/517.9781911507079

5. Брижко В.М. До гносеології категорії «інформація». Інформація і право. 2011. №2(2). URL: http://lib.znau.edu.ua/jirbis2/images/phocagallery/2017/Pryklady_DSTU_8302_2015.pdf (дата звернення: 29.04.2020).

6. Гусєв О.Ю. Проблеми визначення оригіналу електронного доказу в цивільному процесі України.Проблеми законності. 2019. Вип. 147. С. 97-109. doi: https://doi.org/10.215 64/2414-990x.147.175838

7. Зозуля Н. Особливості збору, фіксації, подання та дослідження електронного доказу: погляд юриста та технічного фахівця. Українське право: інформаційно-правовий портал. URL: https://www.ukrainepravo.com/scientific-thought/pravova-pozytsiya/osoblyvosti-zborufiksatsiyi-podannya-ta-doslidzhennya-elektronnogo-dokazu-poglyad-yurysta-ta-tekhni/ _ (дата звернення: 29.04.2020).

8. Каламайко А.Ю. Електронні засоби доказування у цивільному процесі : дис. ... канд. юрид. наук :12.00.03 / Каламайко Андрій Юрійович. Харків, 2016, 242 с.

9. Луспеник Д., Мамченко М. Новелізація цивільного процесу позитивно вплинула на судову практику. Судебно-юридическая газета: веб-сайт. URL: https:/sud.ua/ru/news/ publication/124587-novelizatsiya-tsivilnogo-protsesu-pozitivno-vplinula-nasudovu-praktiku (дата звернення: 29.04.2020).

10. Павлова Ю.С. Електронний документ як джерело доказів у цивільному процесі: дис. ... канд. юрид.наук: 12.00.03 / Павлова Юлія Сергіївна. Одеса, 2019. 239 с.

11. Положення про Єдину судову інформаційно - телекомунікаційну систему (неофіційний текст). Ліга-Закон: веб-портал. URL: http://search.ligazakon.ua/1_doc2.nsf/ link1/NT4424.html (дата звернення: 29.04.2020).

12. Федотов Н.Н. Форензика - компьютерная криминалистика. Москва, 2007. URL: http://kriminalisty.ru/catalog/item50.html (дата звернення: 29.04.2020).

13. Чорний O.С., Антонюк О.І. Електронні докази в цивільному процесі: проблеми застосування на практиці. Вісник студентського наукового товариства ДонНУ імені Василя Стуса, 2018. Т. 1. № 10. URL: http://jvestnik-sss.donnu.edu.ua/article/view/5468 (дата звернення: 29.04.2020).

\section{References:}

1. Casey E. (2010). Handbook of Digital Forensics and Investigation. Burlignton, USA: Elsevier Inc.

2. Guidelines of the Committee of Ministers of the Council of Europe on electronic evidence in civil and administrative proceedings, Adopted by the Committee of Ministers on 
30 January 2019, at the 1335th meeting of theMinisters' Deputies and the Explanation note thereto. Retrieved from: https://rm.coe.int/guidelines-on-electronic-evidence-and-explanatory memorandum/1680968ab5

3. International Organization for Standardization. (2012). Information Technology Security techniques - Guidelines for identification, collection, acquisition and preservation of digital evidence (ISO/IEC Standard No. 27037:2012). Retrieved from: https://www.iso.org/ standard/44381.html

4. Mason S. \& Stanfield A (n.d.). Authenticating electronic evidence. In S. Mason \& D. Seng (2017), (Eds.), Electronic Evidence: Fourth Edition (pp. 193-260). http://dx.doi .org/10.14296/517.9781911507079

5. Bryzhko, V.M. (2011). Do hnoseolohii katehorii "informatsiia" [Towards the gnoseology of the "information" category] Informatsiia i pravo, Information and law, 2(2), 13-20. Retrieved from: http://lib.znau.edu.ua/jirbis2/images/phocagallery/2017/Pryklady_DSTU_8302_2015.pdf [in Ukrainian].

6. Husiev O.Yu. (2019). Problemy vyznachennia oryhinalu elektronnoho dokazu v tsyvilnomu protsesi Ukrainy [Issues of determining the original of electronic evidence in the civil procedure of Ukraine]. Problemy zakonnosti - Problems of Legality, issue 147, 97-109. Retrieved from: https://doi.org/10.21564/2414-990x.147.175838 [in Ukrainian].

7. Zozulia N. (2018, December 12). Osoblyvosti zboru, fiksatsii, podannia ta doslidzhennia elektronnoho dokazu: pohliad yurysta ta tekhnichnoho fakhivtsia [Peculiarities of collection, submission and examination of the electronic evidence: the legal professional and technical expert's perspectives]. Ukrainske Pravo, The Ukrainian Law [Web portal]. Retrieved from: https://www.ukrainepravo.com/scientific-thought/pravova-pozytsiya/osoblyvosti-zboru-fiksatsiyipodannya-ta-doslidzhennya-elektronnogo-dokazu-poglyad-yurysta-ta-tekhni/ [in Ukrainian].

8. Kalamaiko A.Iu. (2016). Elektronni zasoby dokazuvannia u tsyvilnomu protsesi [Electronic means of proof in civil procedure] (Doctoral dissertation). Retrieved from: http://nauka.nlu.edu.ua/download/diss/Kalamaiko/d_Kalamaiko.pdf [in Ukrainian].

9. Luspenyk D., Mamchenko M. (2018, September 3). Novelizatsiia tsyvilnoho protsesu pozytyvno vplynula na sudovu praktyku [The Novelization of The Civil Procedure Had a Positive Impact on Case Law]. Sudebno-yurydycheskaia hazeta, Judicial-Legal Newspaper. Retrieved from: https://sud.ua/ru/news/publication/124587-novelizatsiya-tsivilnogo-protsesu-pozitivnovplinula-na-sudovu-praktiku [in Ukrainian].

10. Pavlova Yu.S. (2019). Elektronnyi dokument yak dzherelo dokaziv u tsyvilnomu protsesi [Electronic document as a source of evidence in civil procedure] (Doctoral dissertation). Retrieved from: http://dspace.onua.edu.ua/handle/11300/11724 [in Ukrainian].

11. Polozhennia pro Yedynu sudovu informatsiino-telekomunikatsiinu system (neofitsiinyi tekst) [The Regulations on the Unified court informational telecommunication system (informally published text)]. Retrieved from: http://search.ligazakon.ua/1_doc2.nsf/link1/NT4424.html [in Ukrainian].

12. Chornyi O.S., Antoniuk O.I. (2018). Elektronni dokazy v tsyvilnomu protsesi: problemy zastosuvannia na praktytsi [Electronic evidence in civil procedure: problems of practical application]. Visnyk studentskoho naukovoho tovarystva DonNU imeni Vasylia Stusa, Journal of the Student Scientific Community of the Donetsk National University named after V. Stus. V.1, 10. 83-88. Retrieved from: http://jvestnik-sss.donnu.edu.ua/article/view/5468 [in Ukrainian].

13. Fedotov N.N. (2007). Forenzyka-kompiuternaia krymynalystyka [Forensic science as a computer criminalistics]. Retrieved from: http://kriminalisty.ru/catalog/item50.html [in Russian]. 